Historia 60, 1, May 2015, pp 47-59

\title{
Guttmann's ingenuity: The Paralympic Games as legacy of the Second World War
}

\author{
Cobus Rademeyer
}

\section{Introduction}

The Second World War, cruel as it was, was largely responsible for the inception of the Stoke Mandeville Games, which later evolved into the Paralympic Games not long after the end of the war. The person behind the initiative that led to the games, Ludwig Guttmann, initially also had to endure the brutality of Hitler Nazism in Germany before fleeing to England. Here he succeeded in developing a rehabilitation programme for spinal cord injury patients at the Stoke Mandeville Hospital near Aylesbury. This programme included sport, physical activity and mild forms of competition that led to the first Stoke Mandeville Games in 1948. Like sport in general, this competition snowballed and based on spectator numbers, became the third largest sporting event in the world, the Paralympic Games. ${ }^{1}$ However, before the evolution of the Paralympic Games can be analysed, more attention should be paid to the man behind the idea of creating a sporting competition for people with disabilities that is on par with the Olympic Games for able-bodied athletes - Ludwig Guttmann.

\section{Ludwig Guttmann (1899-1980)}

Ludwig Guttmann was born into an Orthodox Jewish family on 3 July 1899 in Tost, a small German town in Upper Silesia. Because of the First World War, an acute shortage of trained personnel arose throughout Germany, especially in industry and in hospitals. ${ }^{2}$ Based on this, a regulation was passed that all high school boys could take their final exam earlier on the condition that they join the National Emergency Services on call up for active military duty. Guttmann, who always had the dream of becoming a doctor, seized the opportunity. After completing school in 1917, he joined the Accident Hospital for Mineworkers in Konigshütte, the town where he grew up, as a volunteer orderly.

The author is a senior lecturer in the History Department at Sol Plaatje University. His PhD (History) was awarded at the University of the Free State in 2002: "The Role of Sport Isolation as Factor in the Struggle for a New Political Dispensation in South Africa, 19801992". His current research is on the history of disability sport in South Africa; the history of sport brands in South Africa; and Polish refugees in South Africa, 1943-2013.

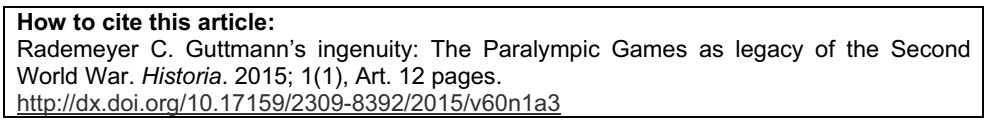

1. Press release on viewer numbers, 2012. Official website of the Paralympic Movement. http://www.paralympic.org/press-release/london-2012-paralympics-proves-worldwide-tvratings-winner Accessed 10 February 2014.

2. E. Schültke, Ludwig Guttman: Emerging Concept of Rehabilitation after Spinal Cord Injury", Journal of the History of the Neurosciences: Basic and Clinical Perspectives, 10, 3, 2001, pp 300-307. 
Here he had his first encounter with paraplegia in the form of a big, strong young coalminer with a fracture of the spine. An accident had paralysed him from the waist down and the doctors held out no hope of recovery. The accepted method of treatment in those days was to encase patients in plaster and isolate them. Normally they would die within weeks. When Guttmann began writing case notes on the matter, he was told "Don't bother; he'll be dead in a few weeks". This is exactly what happened to that young man, who developed a urinary infection, blood poisoning and died within five weeks. Guttmann remembered that patient for the rest of his life. ${ }^{3}$ Later, as a renowned doctor, Guttmann reminisced: "Although I saw many more victims suffering the same fate, it was the picture of that young man which remained indelibly fixed in my memory." 4

During his time at the Hospital for Coalminers, Guttmann picked up a severe throat infection from one of the patients, followed by a sub-thyroid infection. This created problems when Guttmann was called up for military service in 1917, because the drainage tube was still in place and he was rejected by the military. ${ }^{5}$ This gave him the opportunity to begin his medical studies at the University of Breslau. His health improved and he was soon passed as fit for service with the artillery, but he was not called-up by the military again. After the war, he continued his medical studies at the Freiburg University and in 1923, returned to Breslau to start training as a neurosurgeon under Professor Otfrid Foerster. In 1928, he became a practising neurosurgeon in a 300-bed psychiatric clinic at Hamburg University and in 1929 became Foester's assistant. In 1930, he published a wellreceived paper and on the strength of this became a lecturer at the Breslau University. ${ }^{6}$

During the 1930s, Guttmann gained recognition as one of the most renowned neurosurgeons in Europe. By 1933, he had the reputation as the top neurosurgeon in Germany, but at about the same time - in January 1933 - Adolf Hitler became chancellor of Germany. Hitler began implementing laws that prohibited the treatment of non-Jews by Jewish doctors. Furthermore, legislation banned Jewish doctors from practising medicine professionally in public hospitals in Germany.

This meant that Guttmann could only work at the Jewish Hospital in Breslau, where he became the medical director of the hospital. ${ }^{7}$ While in Breslau, Guttmann received several offers of senior medical positions from institutions in North America and South America that would have allowed him to emigrate, but he remained in Breslau through the 1930s, mainly to help other Jews in Germany. ${ }^{8}$

3. J.C. Ross and P. Harris, "A Tribute to Sir Ludwig Guttmann", Paraplegia, 18, 1980, pp 153-156.

4. G. Roberts, "The Inspirational Doctor who Saved Fellow Jews from Nazis before Fleeing Germany to Start Paralympic Games after WWII", Daily Mail, 29 August 2012.

5. D. Whitteridge, "Ludwig Guttmann, 3 July 1899-18 March 1980", Biographical Memoirs of Fellows of the Royal Society, 29, 1983, pp 226-244.

6. Professor Sir Ludwig Guttmann, at http://www.poppaguttmanncelebration.org/poppa2.php Accessed 5 May 2014.

7. C. Hicks, "Paralympics Founder Sir Ludwig Guttmann's Legacy Celebrated in BBC Drama", The Telegraph, 3 August 2012.

8. BBC interview with Eva Loeffler, London, 12 April 2011. Eva Loeffler is the daughter of Ludwig Guttmann. 
Following the attacks on Jewish people and their property on 9 November 1938 , the Kristallnacht, in Germany, ${ }^{9}$ Guttmann ordered his staff to admit anyone who needed treatment without question. The following day he justified his decisions on a case-by-case basis with the Gestapo. Of the 64 admissions, 60 patients escaped arrest and deportation to concentration camps. Apparently, Guttmann also pulled faces and grimaced at the patients from behind the Gestapo officers' backs, signalling to the patients to pull the same expressions and then said: "Look at this man; he's having a fit." ${ }^{10}$ Guttmann's protection of Jews during the Kristallnacht attacks and his consequent actions when the Gestapo officials visited the hospital the next day, contributed to his escalating popularity in nonNazi circles in Germany, even outside the medical fraternity.

Guttmann made tape recordings of his experiences as a Jew in Nazi Germany between 1933 and 1939. According to these recordings, he was neither insulted personally nor mishandled. In 1934, he was present at the burning of the books by non-Aryan authors by the University of Breslau, which he described as very painful to watch. In terms of the 1935 racial legislation, Jews lost all their civil rights. Thus, Jewish doctors had permission to treat only Jewish patients in future. Their official occupation, according to the Nazis, also changed from that of physicians, to Judenbehandler (handlers of Jews). ${ }^{11}$

Thanks to his growing international reputation, Guttmann had a number of offers of work from other countries. ${ }^{12}$ However, the Nazi government always watched him closely. In 1938, when Jewish massacres became more frequent and concentration camps were filling up, the Guatemalan government offered the Guttmann family visas to emigrate, but again they declined.

In 1939, despite the fact that his passport had been impounded by the Gestapo, the German government ordered Ludwig Guttmann to go to Lisbon to treat a good friend of the Portuguese leader, Antonio de Oliveira Salazar, who was believed to be suffering from a brain tumour. Guttmann confronted the Gestapo official and asked him: "How can I travel when you have taken my passport away?" By the next day, his passport was returned to him and he was flown to Lisbon. ${ }^{13}$ Apparently, Salazar did not have a tumour. It was part of the Nazis' attempts to build good relations with Portugal. On his return from Lisbon, Guttmann was given permission to stop over in England for two days. Here he met people from the British Society for the Protection of Science and Learning, and was offered a research post at the Radcliffe Infirmary in Oxford. ${ }^{14}$ Once back in Breslau, Guttmann decided to emigrate to England with his wife and children. On

9. Kristallnacht (Night of Crystal) is also sometimes referred to as the "night of broken glass". The name refers to the wave of violent anti-Jewish massacres, which took place on 9 and 10 November 1938 throughout Germany, annexed Austria, and in areas of the Sudetenland in Czechoslovakia. Kristallnacht (Night of Crystal), United States Holocaust Memorial Museum website, http://www.ushmm.org/wlc/en/article.php?Moduleld=10005201 Accessed 22 May 2014.

10. BBC interview with Eva Loeffler, London, 12 April 2011.

11. Whitteridge, “Ludwig Guttmann”, pp 226-244.

12. Ludwig Guttmann. The Father of the Paralympic Games, Official British Paralympic Association website, at http://paralympics.org.uk/games/ludwig-guttmann Accessed 10 May 2014.

13. BBC interview with Eva Loeffler, London, 12 April 2011.

14. Whitteridge, "Ludwig Guttmann", pp 226-244. 
14 March 1939, he left Germany with his wife Else, their son Dennis aged nine, and a daughter, Eva, who was three years younger.

The Guttmann family arrived in England on a snowy morning, with only ten German Marks each. On their arrival, the immigration officer saw the two small children and called the family to the front of the queue, saying that young children should not stay out in the cold. Not being used to such concerned, soft-spoken administrative officials, Guttmann's wife burst into tears. The officials' act of kindness, Guttmann said, restored his faith in human nature. ${ }^{15}$ On arrival in Oxford, Guttmann began working as neurosurgeon and continued his research on peripheral nerve injuries.

\section{Stoke Mandeville Hospital}

In early 1944, the British government offered Guttmann the position as director of the National Spinal Injuries Unit at Stoke Mandeville Hospital near Aylesbury in Buckinghamshire. In fact, the informal discussion on his appointment began in 1943. Brigadier George Riddoch, who had written a classical paper on spinal injuries in the First World War sent for Guttmann in 1943 and offered him the directorship. Riddoch, who was a consultant neurologist to the Emergency Medical Service and the Army, was known for his kindness to patients and to colleagues and he was most likely aware of Guttmann's under-employment and potential. ${ }^{16}$ Riddoch was planning a new spinal unit that was due to open in time for the casualties expected from the D-Day invasion of Europe. It was agreed that Guttmann should go to the hutted one-storey Emergency Medical Service hospital at Stoke Mandeville and should have a reasonably free hand.

There was a need for such a unit or centre based on the experience of the First World War. Riddoch's paper highlighted the fact that the mortality rate of spinal injuries from the British and American armies during the war was as high as $80 \%$. The few survivors that were lucky enough to survive such injuries lived out their lives as useless and hopeless cripples, regarded as unemployable and unwanted by society. The life expectancy of those who were "crippled" in the First World War was never longer than three months following their injury. ${ }^{17}$ By 1939 , prior to Guttmann's work, the situation improved a little and paraplegics had a life expectancy of about two years whereas previously there had only been a 20 percent chance of surviving for three years. Those who survived were considered incapable of rehabilitation and were confined to bed in hospitals or institutions for the rest of their lives. ${ }^{18}$ Guttmann was very happy to accept the offer Riddoch and the British government made him and saw his new job as a great challenge.

The Centre for Spinal Injuries opened with 24 beds and one patient on 1 March 1944. Ward 10 soon began to fill up with service patients and they must have done well because in May Riddoch ordered that all paraplegics from the D-

15. BBC interview with Eva Loeffler, London, 12 April 2011.

16. S. Goodman, Spirit of Stoke Mandeville: The Story of Sir Ludwig Guttmann (Collins, London, 1986), p 98.

17. I.S. Brittain, The Military and the Modern Paralympic Movement, available at http://theconversation.com/the-military-and-the-modern-paralympic-movement-9366 Accessed 12 March 2014.

18. N. Wedgwood, "Hahn versus Guttmann: Revisiting 'Sports and the Political Movement of Disabled Persons”, Disability and Society, 29, 1, 2014, pp 129-142. 
Day landings be sent to Stoke Mandeville. By August, the centre had nearly 50 patients. ${ }^{19}$ For the next 22 years, all Guttmann's scientific activity focused on solving problems that arose in the pathology, the physiological pathology and treatment of paraplegics. This is unintelligible without a brief outline of the clinical problems involved.

Based on his research, Guttmann already knew that the three great dangers that threatened the paraplegic patient were bedsores, urinary infections and the drop in body temperature of the patients. He noted that bedsores occurred because of necrosis of the skin over bony prominences; if these became infected, the bedsores even extended deeply enough to cause necrosis of the underlying bone. In normal subjects, sitting or lying down in exactly the same position over time, caused enough discomfort to produce a change of body position, but when there is no sensation, movements to sit or lie more comfortably do not occur and pressure points lead to bedsores. ${ }^{20}$

While the majority of patients with war-injures, with medical intervention, physiotherapy and other exercise, returned to their previous levels of health to a certain extent, the one injury that defied contemporary notions of rehabilitation was paralysis caused by spinal cord injuries. The likelihood of death following a paralysing spinal wound was between 47 and 65 percent in the first few months, increasing to 80 percent within three years. ${ }^{21}$ The main factors contributing to early death were complications arising from infection of the urinary tract system and bedsores.

\section{Sport as treatment at Stoke Mandeville Hospital}

Guttmann was of the view that the third factor, the sudden drop in body temperature, would be counteracted by getting patients more actively involved in physical activities. He described the effects of sport on the rehabilitation of people with paraplegia and tetraplegia and stressed that sporting activities enabled people with disabilities to "overcome boredom in hospital and also promoted development of their physical and cardio-respiratory endurance". ${ }^{22}$ Guttmann often told new patients and hospital staff "Games, sport, that is what we must have". ${ }^{23}$ He used sport as a form of remedial exercise and a means of social reintegration and recognition. Teams began with medicine balls at Stoke Mandeville. What started as physiotherapy began to turn into a team sport.

The introduction of sport as treatment at Stoke Mandeville came at about the same time as the implementation of the Disabled Person's Employment Act ${ }^{24}$

19. Whitteridge, "Ludwig Guttmann”, pp 226-244.

20. Whitteridge, "Ludwig Guttmann", pp 226-244.

21. J. Anderson, "Turned into Taxpayers: Paraplegia, Rehabilitation and Sport at Stoke Mandeville, 1944-56", Journal of Contemporary History, 38, 3, 2003, pp 461-475.

22. J.C. Chawla, "Sport for People with Disabilities", British Medical Journal, 308, 6942, 1994, pp 1500-1504.

23. J. Scruton, "Sir Ludwig Guttmann: Creator of a World Sports Movement for the Paralysed and other Disabled", Paraplegia, 17, 1979, p 52.

24. The report on the Rehabilitation and Resettlement of Disabled Persons, or the Tomlinson Report, highlighted rehabilitation as important not only during the war, but also after it was over, and advocated the establishment of more rehabilitation centres to treat the injured effectively. More importantly, the report highlighted the fiscal benefit of ensuring that disabled people were retrained for jobs. Because of the recommendations of the Tomlinson 
in the United Kingdom in $1944 .{ }^{25}$ This Act initiated the provision of facilities to ensure that people with disabilities could fulfil their decade long yearning/interest to participate in sport.

From the start, the daily routine for the patients, whose numbers kept increasing because of the D-Day invasion, was a combination of contemporary rehabilitative exercises and new therapy developed by Guttmann. He was radical in his administration, in that rehabilitation methods applied to those with spinal injuries. Initially, hospital staff members were not very enthusiastic, since they were of the opinion that there was nothing that could be done for these patients. Active physiotherapy and remedial exercises, which started while the patient was still in bed, were adopted in favour of the previous treatment of gentle massage of distorted limbs and bed rest. ${ }^{26}$ As if the physiotherapy and strenuous exercise were not enough, Guttmann also instructed his staff to throw medicine balls at the patients in the ward. ${ }^{27}$ This "playful" rehabilitative initiative quickly developed into a curing process based on competition. It must be kept in mind that the majority of the paraplegics being treated in Stoke Mandeville at this stage - the early 1940s were young ex-servicemen and women in the prime of their lives, often eager to outdo each other.

Guttmann exploited the competitive instincts of the men, thereby getting them to participate actively in their treatment. Competitions held in the wards included the timed "getting dressed exercises", in which the patients had to get out of bed, dress themselves and get into their wheelchairs. ${ }^{28}$ When patients gained sufficient upper body strength through these exercises, the exercises were gradually intensified.

Within months, the Spinal Unit became a place of miracles, hope and determination. A First World War veteran, who had been lying flat on his back for twenty-six years, came to the unit to try one of their new wheelchairs. Six months later, he left - able to walk just with the aid of a stick. ${ }^{29}$

Two separate incidents had a strong impact on the development of sport in wheelchairs at Stoke Mandeville. In 1944, Guttmann walked past a group of patients playing a game using their upended walking sticks, with the curved handle on the ground, pushing themselves around in their wheelchairs attempting to hit a wooden puck. ${ }^{30}$ The same year, Guttmann watched from a window while the medical personnel were having a break outside in the sun, throwing a ball around. Patients sat in their wheelchairs watching the staff, who began to include some of the patients in the game. Seeing the bending and stretching of the patients' bodies

Report, the Disabled Person's (Employment) Act was passed in March 1944. See Anderson, "Turned into Taxpayers", pp 461-475.

25. Anderson, "Turned into Taxpayers", pp 461-475.

26. L. Guttmann, "Victory over Paraplegia", in I. Fraser (ed.), Conquest of Disability (St. Martin's Press, London, 1956), p 65.

27. Goodman, Spirit of Stoke Mandeville, $\mathrm{p} 143$.

28. L. Guttmann, "Rehabilitation after Injuries", in O.F. Guthrie Smith (ed.), Rehabilitation, Reeducation and Remedial Exercises (Baillière, Tindall \& Cox, London, 1949), p 445.

29. International Paralympic Committee Archive, Adenauerallee 212-214, Bonn, Germany, Documentation on the History of the Paralympic Movement, "From Stoke Mandeville Games to Paralympic Games".

30. Goodman, Spirit of Stoke Mandeville, p 143. 
while playing with a ball gave Guttmann an idea. From then on, throwing balls to each other became a regular part of their exercise regime. ${ }^{31}$ Sporting and recreational activities became an increasing important part of the process of rehabilitation. The competitiveness of it increased almost daily as the patients became more skilled and physically more adaptable.

\section{The Stoke Mandeville Games}

The regime of bending and stretching the patients' bodies while throwing a ball to each other as they sat in their wheelchairs started a wheelchair basketball competition at Stoke Mandeville. His emphasis on sport, as part of overall rehabilitation, was re-iterated when Guttmann said "There is no doubt that an employer will not hesitate in appropriate circumstances to employ a paralysed man confined to a wheelchair when he realises that this man is an accomplished sportsman". ${ }^{32}$ The introduction of sport as part of the patients' rehabilitation was an immediate success and led to the first Stoke Mandeville Games for paraplegics in 1948.

A competition was organised between Stoke Mandeville and the Star and Garter Home in Richmond. The games were not only for the patients to compete in but also presented as opportunity to demonstrate the hospital's work to the visiting Minister of Pensions. The wheelchair archery competition, with 14 ex-servicemen and two ex-servicewomen competing, took place on the lawn outside the hospital ward on 28 July 1948. This was the same day that King George VI opened the 1948 Olympic Games in London. The date of the Stoke Mandeville Games was not accidental. Guttmann wanted his games to have a larger forum and his aim was to create an elite sports competition for people with disabilities that would be equivalent to the Olympic Games. ${ }^{33}$

The 1948 Stoke Mandeville Games were the first official competition for athletes with disabilities. The event was such a success that the games took place annually thereafter, adding more sports each year. While exercise and sport remained inextricably linked to rehabilitation, the Stoke Mandeville Games took on a life of its own throughout the 1950s. The archery competition of 1948 was augmented by additional wheelchair sporting codes every year and the number of competitors increased when disabled ex-servicemen from throughout Britain took part. ${ }^{34}$ In 1950, during the British Festival of Sport, two disabled teams played wheelchair netball against each other in front of a crowd of 10000 spectators in London. An archery demonstration also took place, matching paraplegic archers against England's top archers. ${ }^{35}$ This event gave paraplegic sport more public exposure in Britain and assisted in the gaining popularity of the Stoke Mandeville Games.

31. Anderson, "Turned into Taxpayers", pp 461-475.

32. L. Guttmann, Textbook of Sport for the Disabled (University of Queensland Press, Brisbane, 1976), p 112.

33. International Paralympic Committee Archive, Adenauerallee 212-214, Bonn, Documentation on the History of the Paralympic Movement, "From Stoke Mandeville Games to Paralympic Games".

34. Anderson, "Turned into Taxpayers", pp 461-475.

35. Anderson, "Turned into Taxpayers", pp 461-475. 


\section{First international competition}

The year 1952 saw great advancement in the international history of sport for the disabled. ${ }^{36}$ Guttmann always wanted the Stoke Mandeville Games to expand and he wanted international competitors. The medical director of the Military Rehabilitation Centre in Doorn, Holland, asked if he could send a team of war veterans to compete at Stoke Mandeville and Guttmann readily agreed.

Thus, in 1952, a Dutch paraplegic war veterans' team crossed the English Channel to compete against its comrades at Stoke Mandeville. This event was the first international competition for athletes with disabilities. ${ }^{37}$ Henceforth, the games became known as the International Stoke Mandeville Games. The presence of the Dutch team at Stoke Mandeville also created a very strong bond between Stoke Mandeville and Doorn, which led to mutual research partnerships between the Spinal Injury Centre and researchers at Doorn in years to come. A year later, a Canadian team joined the games and, by 1954, Australia, Finland, Egypt and Israel participated. ${ }^{38}$ During this time, the Spinal Injury Centre at Stoke Mandeville Hospital opened its remedial swimming pool and swimming became a competitive sport for the first time.

By 1955, the games were no longer confined to the lawn and forecourt of the Stoke Mandeville premises. Larger areas around the hospital were made available for the increasing number of sporting codes and rapidly growing number of international participants.

The 1957 Stoke Mandeville Games recorded the first representation of all five continents at the games and in 1958, the tenth anniversary of the games, the competition to take part was such that the British team had to hold national games prior to the main Stoke Mandeville Games in order to select a national team.

From 1952 to 1959 , the games were organised by the staff of the Stoke Mandeville hospital. In 1960, a governing body, the International Stoke Mandeville Games Committee (ISMGC), was constituted with Great Britain as permanent member and Dr Ludwig Guttmann as the first president. Although the movement changed names a few times, since its inception in 1952 it underpinned the ideology of the Paralympic movement. The ISMGC changed its name to the International Stoke Mandeville Wheelchair Sports Federation (ISMWSF) and later to the International Wheelchair and Amputee Sport Federation (IWAS), when the ISMWSF merged with the International Sports Organisation for the Disabled (ISOD). The small group of sixteen archers, who gathered to compete on the lawn of the Stoke Mandeville Hospital in 1948, had grown into an international disability sport competition in the space of only twelve years.

36. J. Scruton, Stoke Mandeville: Road to the Paralympics (Peterhouse Press, Aylesbury, 1998) p 70.

37. Dr Ludwig Guttmann, Official British Paralympic Association website, at http://paralympics.org.uk/games/ludwig-guttmann Accessed 2 June 2014.

38. Scruton, Stoke Mandeville: Road to the Paralympics, p 71. 


\section{Guttmann's ingenuity}

\section{The first Paralympic Games}

Towards the end of the fifties, Guttmann held discussions with Dr Antonio Maglio, the director of the spinal centre opened by the Italian Istituto Nazionale per l'Assicurazione controgli Infortuni sul Lavoro (INAIL) and a spinal unit in Rome, regarding the possibility of presenting the 1960 International Stoke Mandeville Games outside Britain for the first time. By now, the Paralympic sporting movement had developed from a local event in England to a renowned international event. ${ }^{39}$ At the 1960 Olympic Games in Rome, the International Olympic Committee recognised the International Stoke Mandeville Games as an affiliated member of the IOC. ${ }^{40}$ The very first Paralympic Games as they are known today took place in Rome shortly after the completion of the 1960 Olympic Games.

Held from 18 to 25 September 1960, 400 athletes from 23 countries competed in eight sporting events: archery, athletics, "dartchery", snooker, swimming, table tennis, wheelchair basketball and wheelchair fencing. ${ }^{41}$ The games were widely seen as the first Paralympic Games, although the name was not yet in use. The name Paralympic Games was only officially recognised by the International Olympic Committee in $1984,{ }^{42}$ and was then backdated to include the 1960 Paralympic Games in Rome. The word Paralympic is derived from the Greek preposition "para" (beside or alongside) which implies that the Paralympic Games have similar status to the Olympic Games and run parallel to them; the two movements exist side by side. ${ }^{43}$

The opening ceremony of the 1960 Paralympic Games drew a crowd of 5 000 spectators, greeting the wheelchair athletes with a great cheer. ${ }^{44}$ There were 400 athletes from 23 different countries competing for 57 medals in eight different sporting codes. Although Italy and Great Britain took home most of the medals, the 1960 Paralympic Games was about far more than just medals. Guttmann himself summed up the Paralympic Games by saying: "The vast majority of competitors and escorts have fully understood the meaning of the Rome Games as a new pattern of reintegration of the paralysed into society, as well as the world of sport." 45

39. G.J. Coetzee, "Betrokkenheid van Suid-Afrika by die Internasionale Stoke MandevilleSpele (1962-1985)", Unpublished MA dissertation, Human Movement Studies, University of Stellenbosch, 1989, p 14.

40. A. Rothberg, A Tribute to our Honorary Patron, Professor Sir Ludwig Guttmann, in The South African Paraplegic Games Association 10th Anniversary, 1970, p 2.

41. Anon., "1960: Athletes Catapult onto the Sports Scene", Paralympian, The Official Magazine of the Paralympic Movement, 3, 2010, p 7.

42. Minutes, International Co-ordinating Committee of World Sports Organisations for the Disabled (ICC), meeting in Papendal, The Netherlands, 3 and 4 February 1985.

43. International Paralympic Committee Archive, Adenauerallee 212-214, Bonn, Documentation on the History of the Paralympic Movement, "The Paralympic Games".

44. International Paralympic Committee Archive, Adenauerallee 212-214, Bonn, Documentation on the History of the Paralympic Movement, "Paralympic Movement: 1960 Games, Rome".

45. International Paralympic Committee Archive, Adenauerallee 212-214, Bonn, Documentation on the History of the Paralympic Movement, "Paralympic Movement: 1960 Games, Rome". 
The ingenuity of Guttmann in creating the Paralympic Games movement changed the perception of disability sport forever. This was best summarised by Pope John XXIII, when he met Guttmann at the 1960 Games. The Pope referred to Guttmann as the "de Coubertin ${ }^{46}$ of the Paralympics" and described his work as transforming "a hopeless and helpless spinally paralysed individual into a taxpayer". ${ }^{47}$ From 1960, the annual International Stoke Mandeville Games still took place at Stoke Mandeville - except in the Olympic year (every fourth year) when they were held in the same city or at the very least in the same country, as where the Olympic Games were hosted.

\section{The legacy of the Paralympic Games}

Between 1960 and 2012 (the year of the most recent Summer Paralympic Games), the Paralympics - the abbreviated name - became a very popular sporting attraction, not only among disabled sportspeople but also among spectators.

One of the main reasons for this is the fact that the Paralympics did not have the same political problems as the Olympic Games. In the late 1970s the IOC was mired in political controversy, and Guttmann claimed that the Paralympic Games were the "true Olympics" because they "portrayed the Olympic ideals of de Coubertin" more clearly. ${ }^{48}$ Guttmann's contribution revolutionised the perception of a person with a disability and provided his rationale for the beginning of the disability sport movement and thus the foundations of disabled movements throughout the world. ${ }^{49}$

With more than 3000 athletes competing at the 2004 Paralympics in Athens, the Paralympics became the second largest international sports gathering of any type after the Summer Olympics. ${ }^{50}$ In the modern era, each consecutive Paralympic Games raises the bar in terms of television production and London 2012 was no different. The 2012 London Paralympics was a television ratings winner with viewers in more countries than ever before, and according to figures published by the International Paralympic Committee, they attracted the biggest international audience in history. ${ }^{51}$ The committee claimed that there was a collective international audience of 3.4 billion people, excluding those in the United Kingdom, who watched the 2012 Games. This figure is almost 1 billion, or 37

46. Baron Pierre de Coubertin, a French aristocrat, was the founding father of the modern Olympic Games. See Official website, Olympic Movement, "Pierre de Coubertin, France, 1863-1937" http://www.olympic.org/content/archive/museum/mosaic/sportequipment/pierre-de-coubertin/ Accessed 17 April 2014.

47. R. Newbury, "Sir Ludwig Guttmann, 1899-1980, The de Coubertin of the Paralympics", La Stampa, 6 September 2012.

48. International Paralympic Committee Archive, Adenauerallee 212-214, Bonn, Documentation on the History of the Paralympic Movement, Letter dated November 6, 1975 from Sir Ludwig Guttmann to Madame Berlioux, secretary general of the IOC.

49. D.A. Greig, "South African Apartheid and the 1976 Toronto Olympiad: A Historical Analysis of Influential Actions and Events Affecting the 5th Paralympic Games", Unpublished MA in Human Kinetics, University of Windsor, Ontario, 2005, p 22.

50. J.R. Gold and M.M. Gold, "Access for All: The Rise of the Paralympic Games, Journal of the Royal Society for the Promotion of Health, 127, 133, 2007, p 134.

51. London Olympic Games 2012, Official Report, Volume 3, p 61 (Organising Committee of the Olympic Games and Paralympic Games Ltd Publication, London, 2013). 
percent higher than at the 2008 Beijing Paralympics. ${ }^{52}$ The Paralympic Games was not only a popular viewer sport in 2012. Ticket sales for spectators increased to 2.72 million. This amounted to almost one million more tickets sold than at the previous Paralympics in Beijing in 2008. ${ }^{53}$ These figures endorsed the fact that after the 2012 Summer Paralympic Games in London, the Paralympics had become the third biggest sporting event in terms of ticket sales behind the Olympic Games and the FIFA Soccer World Cup.

\section{Conclusion}

Between 1948 and 2012, the Stoke Mandeville Games evolved from a small competition to the Paralympic Games, one of the largest sporting events in the world. The 1948 Stoke Mandeville Games came about as an ingenious idea to help patients with spinal cord injuries exercise their bodies. Many of these people were battle scarred from the Second World War.

The pioneering work done by Ludwig Guttmann and the international team he created firmly established a place for the ability and identity of men and women athletes with disabilities in sporting competition. ${ }^{54}$ Although Guttmann always had the ambition to create an international sporting event for people with disabilities equal to the Olympic Games, few people in 1948 would have believed that the London Paralympics in 2012 confirmed just this:

More than a century after the London 1908 Games and 60 years after the 1948 Games became the catalyst for the Paralympic Movement, London 2012 demonstrated how the Paralympic Games have grown far beyond a sporting event and emphasised the important role sport can play in modern society. ${ }^{55}$

The influence of Ludwig Guttmann in initiating competitive disability sport in Britain, establishing the Stoke Mandeville Games and eventually starting the Paralympic Games cannot be underplayed.

After the 1960 Paralympic Games, Professor Ludwig Guttmann continued to conduct research on spinal injuries. The work he did was acknowledged when Britain embraced Guttmann, giving him a knighthood in 1966 and making him a fellow of the Royal Society - honours of which he was extremely proud. ${ }^{56}$ For his enormous contribution to disability sport, a statue of Guttmann was unveiled at the Stoke Mandeville Stadium just before the start of the 2012 Paralympic Games. This will serve as a reminder of the fact that the International Stoke Mandeville Games provided the birthplace and origin for the Paralympic Games.

52. Press release on viewer numbers 2012. Official website of the Paralympic Movement. http://www.paralympic.org/press-release/london-2012-paralympics-proves-worldwide-tvratings-winner Accessed 10 February 2014.

53. Press release on viewer numbers 2012. Official website of the Paralympic Movement. http://www.paralympic.org/press-release/london-2012-paralympics-proves-worldwide-tvratings-winner Accessed 10 February 2014.

54. International Paralympic Committee Archive, Adenauerallee 212-214, Bonn, Documentation on the History of the Paralympic Movement, "International Stoke Mandeville Wheelchair Sports Federation (ISMWSF) History", p 3.

55. London 2012 Olympic Games Official Report, Volume 3, p 124.

56. D. Kirka, "Pioneering Doctor Remembered for Paralympic Idea", The Salt Lake City Tribune, 28 August 2012. 
The Second World War led to many fatalities and even more badly scarred and injured soldiers and civilians. Based on the high fatality rate of paraplegics in the First World War, the expected increase in similar cases during the Second World War, especially after D-Day, and the increased research on spinal injury patients, led to the establishment of the Spinal Care Centre at Stoke Mandeville Hospital in Aylesbury, England. These revolutionary therapeutic methods soon started showing results. The addition of sport as part of his programme led to the first Stoke Mandeville Games in 1948, which became an international competition in 1952. Through the passion and vision for international competition for people with disabilities, this developed into the Paralympic Games in 1960.

Very few sporting enthusiasts around the world really comprehend the connection between the Second World War and the institution known as the Paralympic Games. However, the great success of the 2012 Paralympics did bring new perspective on disabled sport and the influence of Ludwig Guttmann in establishing an international competitive sporting event for people with disabilities. The intervention of technology and advanced prosthetic aids has taken participation in and viewing of disability sport, to a different level. This is far removed from the early beginnings at Stoke Mandeville. It all started with the experimentation with different kinds of "sport" played in wheelchairs, informal sport participation as a form of therapy and helping paraplegics to adapt to their disabilities caused by the Second World War. This resourcefulness of Ludwig Guttmann at Stoke Mandeville turned the brutality of war into a celebration of humanity, as clearly indicated by the successes of the 2012 London Paralympic Games.

\begin{abstract}
In February 1944, the British government requested that Jewish German neurologist Dr Ludwig Guttmann set up a National Spinal Injuries Unit at Stoke Mandeville Hospital near Aylesbury, England. The main task of the unit was to take care of the numerous soldiers and civilians suffering from spinal cord injuries (paraplegics and tetraplegics) because of the Second World War. Starting the unit from scratch, Guttmann introduced a revolutionary new programme of treatment and rehabilitation in which sport was incorporated as a form of remedial exercise and a means of social reintegration and recognition. The use of sport as part of the treatment was so successful that it led to the Stoke Mandeville Games in 1948. Four years later, the games became an international event when a team of paraplegic war veterans from the Netherlands crossed the sea to compete against their British counterparts. The International Stoke Mandeville Games continued on an annual basis and in 1960, they were held outside England for the first time. The International Stoke Mandeville Games of 1960 took place in Rome shortly after the completion of the Olympic Games and became commonly known as the Paralympics. The Paralympics grew in stature and by 2012, based on spectator numbers the event became the third largest sporting event in the world. To many fans, the Paralympic Games is an exciting, yet very emotional event to watch and enjoy. Very few of these fans actually realise that the Paralympics are a legacy of the brutality of the Second World War.
\end{abstract}

Key words: Sports history; sport and disability; Ludwig Guttmann; Paralympic Games. 


\section{Opsomming}

In Februarie 1944 het die Britse regering die Joods-gebore Duitse neurochirurg Dr Ludwig Guttmann gevra om die National Spinal Injuries Unit by Stoke Mandeville hospitaal naby Aylesbury in Engeland te bestuur. Die vernaamste taak van die eenheid was om na die talle soldate en burgerlikes wat rugmurgbeserings opgedoen het (parapleë en tetrapleë) as gevolg van die Tweede Wêreldoorlog om te sien. Guttmann het die eenheid van nuuts af opgebou en het 'n revolusionêre nuwe program van behandeling en rehabilitasie gebruik as ' $n$ vorm van regstellende oefening en ' $n$ middel van sosiale integrasie en erkenning vir sy pasiënte. Die gebruik van sport as deel van die behandeling was so suksesvol dat dit gelei het tot die ontstaan van die Stoke Mandeville Spele in 1948. Vier jaar later het die Spele internasionale status verwerf toe 'n span Nederlandse oorlogsveterane teen hul Britse eweknieë kom kompeteer het. Die Internasionale Stoke Mandeville Spele is daarna jaarliks aangebied. In 1960 is dit net na die Olimpiese Spele, ook in Rome, aangebied, en het bekend geword as die eerste Paralimpiese Spele. Die Paralimpiese Spele het toegeneem in statuur en na die 2012 Spele in Londen was dit gevestig as die derde grootste toeskouersport ter wêreld. Vir menigte sport entoesiaste is die Paralimpiese Spele opwindend, dog baie emosioneel om te volg. Baie min van hierdie entoesiaste besef egter dat die Paralimpiese Spele ' $n$ direkte uitvloeisel is van die wreedhede van die Tweede Wêreldoorlog.

Sleutelwoorde: Sport geskiedenis; sport en gestremdheid; Ludwig Guttmann; Paralimpiese Spele. 